\title{
Orobanche infestation in Indian Brassica juncea L. in Ajmer districts of Rajasthan and its management
}

\section{HIRA LAL, DEVENDRA SINGH AND BHANWAR LAL JAT}

\author{
Article Chronicle : \\ Received : \\ 27.03.2017; \\ Revised: \\ 01.05.2017; \\ Accepted : \\ 15.05.2017
}

Key Words : Neem, Orobanche, Brassica juncea, DAS, Fertilizer

Author for correspondence : HIRA LAL Department of Agriculture, Bhagwant University, AJMER (RAJASTHAN) INDIA Email : rajan.meghwal786 @ gmail.com

See end of the article for Coopted authors'
ABSTRACT : Orobanche aegyptiaca started to emerge above ground 40 DAS of Indian mustard. Significant difference was observed in number of Orobanche shoots $\mathrm{m}^{-2}$, fresh and dry weight of Orobanche shoots $\mathrm{m}^{-2}$ and visual control of Orobanche in mustard crop due to different treatments. At 60DAS, treatments $\mathrm{T}_{3}, \mathrm{~T}_{7}, \mathrm{~T}_{8}$ and $\mathrm{T}_{9}$ were observed most effective with no shoots, fresh weight and dry weight of Orobanche $\mathrm{m}^{-2}$, hence, providing 100 per cent control of Orobanche at 65DAS of mustard. At 90DAS, 120DAS and harvest, treatment $\mathrm{T}_{9}$ was found statistically at par with $\mathrm{T}_{7}$ and $\mathrm{T}_{8}$ in reducing the number, fresh and dry weight of Orobanche shoots, hence, providing the maximum visual control at 95, 125DAS and at harvest, respectively. Increasing the application of nitrogen in mustard decreased the population, fresh weight and dry weight of Orobanche and increased the control of Orobanche in $\mathrm{T}_{9}$ over $\mathrm{T}_{8}$ probably because of detrimental effect of the nitrogenous fertilizers on the parasitic infestation. A significant difference in plant height and dry matter accumulation plant $^{-1}$ of mustard was observed due to different treatments. The plant height and dry matter accumulation plant ${ }^{-1}$ in treatment $\mathrm{T}_{9}$ i.e. 125 per cent of recommended fertilizer + foliar spray of glyphosate at 25 and $50 \mathrm{~g} \mathrm{ha}^{-1}+1.0 \%$ solution of $\left(\mathrm{NH}_{4}\right)_{2} \mathrm{SO}_{4}$ at 25 and 55DAS, respectively was higher due to higher dose of N and P and excellent control of Orobanche during its life cycle. Different treatments resulted in significant difference in crop growth rate of Indian mustard from sowing upto 130DAS and thereafter it remained non-significant. Among different treatments, 125 per cent of recommended fertilizer + foliar spray of glyphosate at 25 and $50 \mathrm{~g} \mathrm{ha}^{-1}+1.0 \%$ solution of $\left(\mathrm{NH}_{4}\right)_{2} \mathrm{SO}_{4}$ at 25 and 55DAS, respectively $\left(\mathrm{T}_{9}\right)$ resulted in highest CGR which might be due to better control of Orobanche coupled with beneficial effects of higher dose of $\mathrm{N}$ and $\mathrm{P}$ on mustard at active vegetative stages as a result of enhancement in cell multiplication, cell elongation and cell expression in the plant body which ultimately increased the CGR. Among the different treatments, number of primary branches at harvest stage were found maximum in treatment $T_{9}$ which was at par with treatment $T_{7}$ but significantly higher over rest of the treatments. Number of siliquae plant ${ }^{-1}$ at harvest stage were recorded maximum in treatment $\mathrm{T}_{9}$ which was at par with treatment $\mathrm{T}_{7}$ but significantly higher over rest of the treatments. $\mathrm{T}_{9}$ recorded maximum number of siliquae because higher nutrients help in more number of branches, mainly the secondary branches and resulting higher number of siliquae plant ${ }^{-1}$ at higher dose of fertilizers. Similarly, number of siliquae branch ${ }^{-1}$ were maximum under 125 per cent of recommended fertilizer + foliar spray of glyphosate at 25 and $50 \mathrm{~g} \mathrm{ha}^{-1}+1.0 \%$ solution of $\left(\mathrm{NH}_{4}\right)_{2} \mathrm{SO}_{4}$ at 25 and 55DAS, respectively $\left(\mathrm{T}_{9}\right)$ which was significantly superior over all other treatments. Maximum siliqua length $(\mathrm{cm})$ and 1,000-grain weight $(\mathrm{g})$ was observed with 125 per cent of recommended fertilizer + foliar spray of glyphosate at 25 and $50 \mathrm{~g} \mathrm{ha}^{-1}+1.0 \%$ solution of $\left(\mathrm{NH}_{4}\right)_{2} \mathrm{SO}_{4}$ at 25 and 55DAS, respectively $\left(\mathrm{T}_{9}\right)$ which was at par with foliar spray of glyphosate at 25 and $50 \mathrm{~g} \mathrm{ha}^{-1}+1.0 \%$ solution of $\left(\mathrm{NH}_{4}\right)_{2} \mathrm{SO}_{4}$ at 25 and 55DAS, respectively $\left(\mathrm{T}_{7}\right)$ and superior over all other treatments. Similarly, grains siliqua ${ }^{-1}$ were recorded maximum in treatment $\mathrm{T}_{9}$ which was found statistically at par with $\mathrm{T}_{2}, \mathrm{~T}_{3}, \mathrm{~T}_{6}, \mathrm{~T}_{7}$ and $\mathrm{T}_{8}$ and significantly higher than other treatments. Grain yield and biological yield of Indian mustard varied 